Margit Osterloh \& Bruno S. Frey

\title{
Dealing With Randomness
}

\begin{abstract}
Decisions based on randomness are often taken to be "irrational" or "arbitrary". The conventional strategy is to fight randomness; a more recent one is to accept and even celebrate randomness. We focus on a third approach that employs randomness as a managerial and social decision-making mechanism in a purposeful way. We argue that Controlled Random Decisions provide considerable advantages. They allow outsiders as well as novel ideas to have an influence, and they work against corruption. When persons and projects are selected, there must be a careful pre-selection. Controlled Random Decisions should be discussed and employed more extensively.
\end{abstract}

Keywords: decision making, risk, (fundamental) uncertainty, randomness

(JEL: D81, D83, M12, M14, M38)

\section{Introduction}

In managerial decision making randomness or luck is mostly considered to be irrational or arbitrary, and a nuisance to be eliminated. External forces are assumed to lead to unpredictable outcomes; they therefore have to be detected and translated into manageable risks. Randomness has to be fought by intense information acquisition, proper statistical methods, or good heuristics.

However, this view has been questioned by the experience of financial shocks, natural and nuclear disasters, and disruptive innovations. They prompted the idea that in managerial decision-making we do not only have to face risks, i.e. conditions in which the probabilities of possible alternatives are known, or uncertainty, i.e. situations in which the probabilities of possible alternatives are unknown. Rather we have to take into account fundamental uncertainty or ambiguity as a special kind of randomness. (Knight, 1921; Taleb, 2001, 2007). In this case the alternatives that may occur are unknown. We have to deal not only with "known unknowns" but "unknown unknowns" (Luft \& Ingham, 1955) or "Black Swans" (Taleb, 2007) that are so unexpected that they are not considered. They can neither be anticipated on the basis of experience or theories nor on the basis of additional information (Minkler, 1993). Examples are e.g. the colossal underestimation of the importance of home computers in the 1980ies (Courtney et al., 1997), the opening of the Berlin Wall and of the inner German border in November 1989, and the financial crisis in 2008. The latter prompted Queen Elizabeth II to ask why nobody had noticed that the credit crunch was on its way (Besley \& Hennessy, 2009). 
Recently, a third form of randomness in managerial decision-making has been considered. It has a long, but little-known, history: the use of randomness in a purposeful way. It has been successfully applied in ancient Athens and the "golden times" of Venice (see e.g. Buchstein, 2009, 2020). It is presently discussed as a decision mechanisms that contributes to reforms in the political sphere (e.g. Frey \& Osterloh, 2016; Van Reybrouck, 2016), but in the management literature is rarely featured as a decision-making mechanism for business processes, (for exceptions, see Dwenger et al., 2014; Zeitoun et al., 2014; Liu \& De Rond, 2016; Berger et al., forthcoming; Osterloh \& Frey, 2019). Neither is it used in today's political decision making (for exceptions see e.g. Buchstein, 2009; Van Reybrouck, 2016).

Our paper discusses three different ways of dealing with randomness, their advantages and disadvantages, and how to profit from it in the field of managerial decision-making and in politics. Section II shortly discusses the conventional strategies to come to grips with unforeseen events, namely fighting randomness. Section III considers accepting randomness and to even celebrate it. The insight that fundamental uncertainty is unavoidable can indeed be exploited to the advantage of firms as well as individuals. Section $I V$ analyzes possibilities to employ randomness as a managerial and social decision-making mechanism in a purposeful way. This section forms the major part of our paper. It deviates basically from taking randomness as an irrational feature of life. Rather, randomness is used to improve business and society in various respects.

\section{Fighting Randomness}

In conventional management decision-making random events are seen as disturbances disrupting plans and thwarting strategies. Consequently, randomness is considered to be incomplete knowledge and as a failure to be overcome. It constitutes the opposite of a causal explanation of events. Hence an effort must be made to identify the hidden causal structure of cause and effect.

Statistical theory offers a host of procedures to determine whether, and to what extent, one variable influences another variable, including the possibility that the causal effects may take place simultaneously in both directions. The theoretical background consists in models of rational behaviour that imply omniscience.

Later on the models of costly rationality (Radner, 2000), bounded rationality (Simon, 1955; Grandori, 2013), and ecological rationality (Gigerenzer et al., 1999) gained influence. They take into account the limited ability of people to deal with random events. In order to overcome this weakness and to fight randomness, heuristics were recommended that focus on the most relevant aspects of a situation and lead to accurate inferences. In this vein Gigerenzer et al. (1999; see also Gigerenzer \& Selten, 2002) developed an "adaptive toolbox" to find out domainspecific heuristics as responses to a world of uncertainty and randomness. 
"Behavioural Economics" (more appropriately called "Psychological Economics") as introduced by Tversky and Kahneman (1974) is more sceptical whether "ecological rationality" can overcome uncertainty. It links heuristics to cognitive biases and demonstrates that individuals often fail to make accurate decisions. People find it difficult to deal with randomness. They systematically tend to overestimate or underestimate probabilities e.g. in the form of representativeness bias (judgments influenced by what is typical), availability bias (judgment based on what comes easily to mind) or anchoring (judgments relying on what comes first) (see Russo \& Schoemaker, 1989; Kahneman, 2011; and for many examples, Dobelli, 2013). However, Behavioral Economics tends to disregard that while individuals are not well prepared to deal with probabilities this need not necessarily be the case in the aggregate. Markets are sometimes able to reduce and even eradicate biased evaluations of probabilities by individuals (Frey \& Eichenberger, 1994; Frey \& Stutzer, 2006a; Frey \& Gallus, 2013). Recently "Nudging” (Thaler \& Sunstein, 2009) has been heavily discussed as a tool to overcome decision traps and the failures when dealing with randomness.

All these endeavors to overcome the disturbances caused by uncertainty have in common that the underlying normative goal is to fight randomness in a rational way. Nevertheless it is claimed to have abandoned the rational "homo oeconomicus" (Sugden, 2017).

\section{Accept and Celebrate Randomness}

Randomness in the form of fundamental uncertainty is unavoidable and can be fought only to a certain extent (for examples in Strategic Management see Schreyögg \& Steinmann, 1987; Simons, 1995; Courtney et al., 1997). This insight leads to approaches that accept randomness and even celebrate it in order to exploit randomness to the advantage of firms as well as individuals (Arenberg, 2020).

Taleb $(2001,2007)$ made these approaches popular. He argues that individuals tend to see causalities where there are none. They have an inner drive to deal with the world they live in by making an effort to explain it. The education received - especially in Western countries - strongly supports this attitude. We are taught, and pressured by our environment, to seek an explanation for events - even if they are purely random. But the possibility to do so is highly overestimated; we are "fooled by randomness" (Taleb, 2001). Randomness is closely connected to fragility, where an object or person is damaged by an unexpected shock. The intuitive reaction is to resort to robustness. However, that means a situation of not being affected by unforeseen events. The true opposite to fragility is something quite different, namely a situation in which unexpected events are beneficial. Taleb (2012) calls them "antifragile" as there is no word in any language to positively describe this. In this view, uncalculated randomness has not to be reduced, but must be celebrated in such a way that business and society can benefit from it. Antifragility gives us the opportu- 
nity to learn from failures, to grow from mistakes, and to be open for unexpected discoveries.

Openness to unexpected discoveries has for a long time been celebrated with the idea of serendipity (Merton \& Barber, 2004). Serendipity effects provide answers to unasked questions (Stephan, 1996; Simonton, 2004). The best-known cases are the discovery of America, or the discovery of Penicillin, due to chance events which were skillfully exploited. Other examples are the invention of dynamite, X-rays, radio activity, LSD, or post-its. Serendipity and luck also play a role in management (Barney, 1986; Liu \& De Rond, 2016). For example, Bill Gates (as quoted in Gladwell, 2008, p. 55) explains his success as an incredibly lucky series of events. In any case, one has to be open for unexpected events, as "chance favours the prepared mind", as a quote attributed to Louis Pasteur says.

Another approach to celebrate randomness is to exploit the biases of other actors in order to gain a competitive advantage for a firm (Amit \& Schoemaker, 1993; Denrell et al., 2019). Such biases caused by misinterpretations of randomness only then create a strategic opportunity if there are barriers that are not easy to detect and to take advantage of. Misattribution of luck or randomness is such a barrier, in particular ignoring the "regression to the mean". Extreme performances tend to be followed by less extreme ones. Supreme performance usually is associated with extreme luck unlikely to persist. The process is characterized by randomness. Therefore future performance will regress to the mean. Nevertheless most people tend to explain extreme performance causally. Such misattributions can be exploited if a firm overcomes behavioural barriers to learn about them more effectively than rivals (Denrell et al., 2019).

Randomness can also be exploited by individuals for their own benefit. Drastic examples are managers who regularly attribute success to their own activities while failures are said to be due to bad luck (Liu, 2020). Exceptional management performances may indicate luck because extreme performances are more likely to result from extreme circumstances (Denrell \& Liu, 2012). As the skill level of CEOs of prominent firms can be assumed to be quite similar, different outcomes are strongly determined by situational factors. These star performances attract media attention. The extreme personalization of prominent CEOs in the media reinforces the extreme overestimation of their abilities and performance, which is further reinforced by so called "CEO profiling". ${ }^{1}$ It conveys to the public the idea that the success of a company depends solely on top management.

There are several reasons why such an attribution is doubtful (Liu \& De Rond, 2016). The first is the common bias to ignore "regression to the mean" that often is exploited by managers in order to profile themselves as heroes. The second reason is that one does not know what would have happened without the particular manager

1 See e.g. Peel (2018) on „how do you leverage your executives in PR superstars?“. 
being in charge. A satisfactory counterfactual analysis cannot be undertaken as it is impossible to determine the initial conditions affecting the subsequent course of events. The third reason relates to how individuals build alternative histories after an event occurred. What has happened in fact is more salient than what did not happen. This has been experimentally established by the hindsight bias (Fischhoff, 1975). Forth, those who are successful will be increasingly supported which is known as the Halo and Matthew effect ("the rich get richer, and the poor get poorer"). Lucky managers receive more and better resources, higher promotion opportunities and more attention because they are allegedly so skillful. As a result they induce other people to overestimate the role of skill and to underestimate the role of randomness to their advantage. They thus create an naïve meritocracy (Pluchino et al., 2018) serving to provide legitimacy to huge management salaries.

\section{Consciously Applying Random Decision-Making}

Purposefully applied random choice is an underdeveloped research area though in every day life we know random decisions in various applications and for different goals (see e.g. Heinzmann, 2020). An example is the random selection of tourists and business people for security control at airports. The goal is to create purposeful uncertainty in order to discourage terrorists. Another example is the allocation of indivisible goods between children (or green cards, college opportunities or even kidneys between adults) if demand is higher than supply. Here the goal is fairness. A third example relates to surprise menus at restaurants or last minute holiday bookings. The motive might be the pleasure of being surprised, the avoidance of having made difficult trade-offs, or the psychic costs of decision-making (Simonson, 1990; Dwenger et al., 2014).

Less known are random decision-mechanism to take socio-political decisions. Such random procedures were successfully applied in ancient Athens, in Venice and Florence in the Medieval Age, and in many countries in Europe until the French Revolution (see e.g. Manin, 1997; Buchstein, 2009; Sintomer, 2011; Van Reybrouck, 2016). In the $18^{\text {th }}$ century at the university of Basel vacant professorial chairs were filled by lot from a list of three candidates (Burckhardt, 1916; Stolz, 1986; Frey \& Osterloh, 2016; Berger et al., forthcoming).

Today, few organizations apply random selection methods (Frey, 2020). The Coptic Pope is appointed by random selection from three candidates, the Amish choose their leaders randomly (Shoucri, 1991; Boochs, 2004; Frey \& Steiner, 2014). Well known is the random selection of juries in Anglo-Saxon legal systems like the UK (Crown Prosecution Service, 2018) and United States (Administrative Office of the U.S. Courts, 2019; see also Sintomer, 2011). The movement for deliberative democracy (Fishkin, 1991; Dryzek, 2000; Habermas, 2006) suggests that the citizens participating in the consultation or decision-making process should be chosen by lot. Similar suggestions have been made with regard to national politics (Mans- 
bridge, 2005), international organizations (Frey \& Stutzer, 2006b), and decision making at the workplace (Emery, 1989). Grants are sometimes partially allocated by random selection methods. ${ }^{2}$ Partly random selection to choose the papers to be published has been suggested (Oswald, 2019; Osterloh \& Frey, 2019). In Switzerland, a popular initiative has recently been started to draw federal judges from a pool selected by an expert committee. ${ }^{3}$ Recently, the media shows some interest in random selection of politicians (Bridle, 2018). However, modern organizations rarely use partly random choice methods.

Random choice (sometimes called sortition or aleatoric procedures, derived from the Latin word alea for dice) is one among several socio-political decision-making mechanisms such as the market, democracy, hierarchy (bureaucracy), bargaining or tradition (Frey, 1983). It has many desirable characteristics but, of course, also some negative aspects. Advantages and disadvantages must be compared to those of other social decision-making procedures.

\section{Advantages of Purposeful Random Selection}

Random procedures have the following advantages over other decision-making systems (e.g. Frey, 1969; Intriligator, 1973; Carson \& Martin, 1999; Buchstein, 2009, 2010, 2020; Sintomer, 2011, 2018; Frey \& Osterloh, 2016). First, random decisions make it possible to well represent the underlying basic population. The weight of each group is reflected according to its weight in the basic population. Those parts of the population otherwise disregarded in the political process are adequately represented. Quotas are no longer needed to attain a representative selection.

Second, random procedures help to prevent undue influences on public decisions. If correctly made, they are immune to human intervention. The influence of particular interest groups via spending money, old boys networks, and corruption is reduced. Random choice prevents discrimination according to race, sex, age or origin.

Third, creative outsiders gain easier access to influential positions. The lottery is therefore a true search engine for new ideas and talents. Conversely, people who otherwise have little preference for competition are encouraged to apply. ${ }^{4}$ Thus, the pool of qualified candidates is enlarged.

Fourth, interests neglected at the time of a political decision are automatically represented according to their importance in the basic population. Random choice takes

2 Examples are the Health Research Council of New Zealand (2019) and the German Volkswagen Foundation (2018).

3 See https://www.bk.admin.ch/ch/d/pore/vi/vis486.html, retrieved 17.7.2019.

4 Competition is by no means always beneficial, in particular with competition characterized by contrastive comparison. This kind of competition emphasizes individual's inferiority in comparison to others, leading to feelings of envy. In contrast, assimilative comparison focuses on feelings of aspiration, see Sapienza \& Weibel (2017). 
into account aspects previously unknown and therefore impossible to represent by quotas.

Fifth, random choice maintains the stability and continuity of government when there are strong conflicts between various groups in the population. Each of these groups sees a chance to exert influence in the future, even if at present an opposing group is in power. No group feels oppressed in future periods.

Finally, random selection enables a different form of representation in basic decision bodies like parliaments, local citizen forums, or working teams. The person selected randomly is not an agent or a representative of other people to whom he or she is accountable. Instead, the person selected by lot stands for him- or herself. He or she is representative solely in a statistical sense. Therefore, no principal-agent-conflict, nor conflict between the elected representative and his or her constituency, can arise. Instead, there is an obligation to take part in deliberative processes in the community one is member of. 5

\section{Disadvantages of Purposeful Random Selection}

The following undesired effects of random decisions should be taken into account. First, random procedures do not identify skills and qualifications. Persons selected by lot may be incapable of performing the required tasks. Random mechanisms make sense if the basic population is determined according to the skill and qualifications needed for a certain task. It also makes sense in generating collective decision-making bodies that represent the preferences of different groups. These bodies then select the best candidate according to conventional criteria. Therefore most applications of random selection mechanisms use a two-step procedure of conventional pre-selection and random selection, called focal random selection.

Second, in politics randomly chosen citizen may refuse to take the political offices to which they are selected. This problem can be mitigated by appealing to every person to follow his or her citizen duty. A more effective procedure may be to offer randomly chosen persons a financial compensation inducing them to accept the attributed political task.

Third, people might believe that random selection is irrational or arbitrary. To counter this argument one should take into account the possible damages produced by corruption as well as by many decision anomalies and biases, as impressively shown by Kahneman (2011). In many cases controlled randomness is less irrational than uncontrolled biases, corruption or old boys' networks.

The conditions under which the advantages of random decisions outperform the disadvantages must be carefully investigated. In the following we sketch possible applications in the management field and in politics.

5 See also the difference in the theory of representation of Hanna Pitkin (1967) between "standing for" and "acting for". 


\section{Application to Management}

In management, random selection can be applied on various levels. On the Corporate Governance level companies could install a second chamber in the supervisory board formed according to a random choice among stakeholders in order to give them a vote. This procedure has been suggested by Zeitoun et al. (2014). According to the Resource-Based View of Strategic Management (Barney, 1991), sustainable competitive advantages can be gained only if stakeholders' non-contractible firmspecific investments are protected. In order to make this possible, the many different stakeholders (such as employees, suppliers, customers, and the local community) could be selected randomly to participate in the decision bodies of the firm, preferably in the board. They have the task to reconcile the interests of the various stakeholders in such a way that they are encouraged to undertake firm-specific investments.

On the top-management level focal random selection could also be used in order to improve management quality. A shortlist of candidates could first be determined competitively. The strict selection process ensures that the candidates in the pool have the required skills and characteristics. Out of this shortlist the winning candidate is chosen randomly. This procedure has been suggested by Frey et al. (2020). It has several advantages: First, managers selected for a top position in a firm by a random draw out of a shortlist of able mangers are less susceptible to hubris and abuse of power. Excessive manager salaries are less likely to occur under these conditions. Second, losers retain their face and self-confidence, therefore cooperation between winners and losers will be improved. Third, candidates who are otherwise afraid of losing face will compete, thereby increasing the pool of candidates. Fourth, people act more socially when they know that they have been favored by fate (Frank, 2016). This has been recently tested and confirmed in a laboratory experiment (Berger et al., forthcoming). Fifth, when a careful pre-selection has taken place, the selected top candidates may meet different performance criteria, but all on the short list would have the necessary qualification for the vacant post. The better the preselection, the smaller is the difference between candidates with respect to suitability. Under this condition, random selection is fairer than conventional procedures during which old boys' networks may play an unfavorable role.

Random selection out of a pre-selected shortlist may also help to mitigate the gender gap in top management. Today, women have a better formal education and achieve higher scores than men (OECD, 2015). Female representation in top management is positively associated with organizational performance (Rost \& Osterloh, 2010; Dawson et al., 2014) and less irregularities in financial statements (Gupta et al., 2019). Yet, women are still heavily underrepresented at upper echelons of management. Recently, this gap has been explained by the difference in competitive behaviour between men and women. It has been demonstrated that on average women - especially high-performing women - are less willing to compete than men. 
They opt out of competitions more than men, even when they are equally or more qualified (Niederle \& Vesterlund, 2007, 2010; Balafoutas \& Sutter, 2012; Niederle et al., 2013). In order to encourage high-ability-women to "throw their hat into the ring" (i.e. to become a candidate for the shortlist) it might be useful to avoid competition within the ring. Such a procedure has been proposed by Osterloh et al. (2019). With conventional pre-selection, a shortlist consisting of suitable candidates could be made along with announcing that the vacant position is drawn by lot from the shortlist. It is expected that more women apply in the final round through this process. This proposition can be tested in laboratory and field experiments. If it works, then not only the gender gap in top management could be mitigated, but the pool of high-quality candidates would be increased.

\section{Applications to Politics}

In politics random selection is a measure to integrate people who otherwise would not take part in political decision-making. In most democracies, the political process is characterized by strong social segmentation. On the one hand, high-income recipients and educated people are overrepresented in parliament and other political decision bodies. On the other hand, voter turnout is socially selective. High-income earners and educated people vote much more often than low-income recipients. This means that the concerns of the low-paid and less educated are not adequately represented in the political decision-making process. As a result, their political interest decreases (Benz \& Stutzer, 2004). Here, random selection favors social groups that were previously underrepresented in the political process. The members of parliament can be randomly chosen to a second chamber. The members of the first chamber would be determined according to the traditional election procedure. In analogy to the British "House of Lords" this could be called "House of Lots" (Buchstein, 2009).

So-called "Citizen Forums" are a weaker form of this idea. (see Heinzmann, 2020). 100 to 200 citizens are randomly drawn into a committee in which they discuss political issues. The result better reflects the social discourse than the procedures in representative democracy. Such Citizen Forums have been convened in the Netherlands, Ireland and the Canadian provinces of British Columbia and Ontario. In Ireland, Citizens' Forums have led to two major constitutional changes in recent years. The first Forum took place in 2012. The panel's recommendations on "marriage for all" were endorsed by parliament and finally adopted in a referendum with high approval. A subsequent Citizens' Forum in 2016 discussed, among other things, the legalisation of abortion. All participants were chosen by lot from the population in order to weaken the influence of politicians. The recommendation by the Citizens' Forum on abortion was also adopted with high approval in a 2018 referendum.

Random selection can also be envisaged for the executive branch, provided a formal minimal qualification is secured. The members of government could be chosen by 
lot from the elected members of parliament. This would over time guarantee a composition of the government according to the strength of parties, gender, religion and regions. Also International Organizations that are subject to democracy deficits could be fruitfully reformed by a random selection of representatives (Frey \& Stutzer, 2006b).

\section{Concluding Remarks}

Decisions based on randomness may be considered "irrational" or "arbitrary" by the public, and therefore taken to be illegitimate. However, each of the various ways to deal with randomness has its advantages and disadvantages: The conventional strategy is to fight randomness; a more recent one is to accept randomness and to even celebrate it. We focus on employing randomness as a managerial and social decision-making mechanism in a purposeful way. This approach deviates basically from taking randomness as an irrational feature of life. Rather, randomness is used to improve business and society in various respects.

Controlled Random Decisions provide considerable advantages compared to other decision-making systems. In particular, they allow outsiders as well as unconventional and novel ideas to have an influence, and they work against corruption and old boy's networks. Random decisions do not take into account issues of content. As a consequence, when persons and projects are selected, there must be a careful pre-selection. Thus, usually persons must be chosen that are able to master the given task. For this reason, random decisions cannot be used in all instances but only under conditions for which a careful balancing of the advantages and disadvantages has been undertaken. They must be put into the context of other decision-making procedures like e.g. markets, hierarchical selection, bargaining, voting or deliberation.

Controlled Random Decisions should receive more attention than has been the case in modern times. Future research should analyse specific applications of this approach in various situations, in particular in the context of firms. It can be speculated that there are many conditions in which Controlled Random Decisions are suitable and may raise economic and social welfare.

\section{References}

Administrative Office of the U.S. Courts. (2019). Learn About Jury Service. Retrieved 10.7.2019, from https://www.uscourts.gov/services-forms/jury-service/learn-about-jury-service.

Amit, R., \& Schoemaker, P.J.H. (1993). Strategic assets and organizational rent. Strategic Management Journal, 14(1), 33-46.

Arenberg, P. (2020). Making use of unplanned events. The influence of random events on the success of managers. ZFO Zeitschrift Führung \& Organisation, Special issue on "Leadership and Luck" (forthcoming). 
Balafoutas, L., \& Sutter, M. (2012). Affirmative action policies promote women and do not harm efficiency in the laboratory. Science, 335(6068), 579-582.

Barney, J.B. (1986). Strategic factor markets: Expectations, luck, and business strategy. Management Science, 32(10), 1231-1241.

Barney, J.B. (1991). Firm Resources and Sustained Competitive Advantages. Journal of Management, 17, 99-120.

Benz, M., \& Stutzer, A. (2004). Are voters better informed when they have a larger say in politics? Evidence for the European Union and Switzerland. Public Choice, 119(1-2), 31-59.

Berger, J., Osterloh, M., Rost, K., \& Ehrmann, T. (forthcoming). How to prevent leadership hubris. Comparing competitive selections, lotteries, and their combination. Leadership Quarterly.

Besley, T., \& Hennessy, P. (2009). The Global Financial Crisis. Why didn't Anybody Notice? British Academy Review, 14, 8-10.

Boochs, W. (2004). Geschichte und Geist der koptischen Kirche. Langwarden: Bernardus-Verlag.

Bridle, J. (2018). How can be break the Brexit deadlock? Ask Ancient Athens. Retrieved 25.12.2018, from https:/www.theguardian.com/commentisfree/2018/dec/25/break-brexit-dea dlock-ancient-athens-sortition.

Buchstein, H. (2009). Demokratie und Lotterie. Frankfurt am Main: Campus Verlag.

Buchstein, H. (2010). Reviving Randomness for Political Rationality: Elements of a Theory of Aleatory Democracy. Constellations, 17(3), 435-454.

Buchstein, H. (2020). Random decisison from a historic point of view. ZFO Führung \& Organisation, Special issue on "Leadership and Luck"(forthcoming).

Burckhardt, A. (1916). Ueber die Wahlart der Basler Professoren, besonders im 18.Jahrhundert. Basler Zeitschrift für Geschichte und Altertumskunde, 15, 28-46.

Carson, L., \& Martin, B. (1999). Random Selection in Politics. Westport, CT: Praeger Publishers.

Courtney, H., Kirkland, J., \& Viguerie, P. (1997). Strategy under Uncertainty. Harvard Business Review, 75(6), 66-79.

Crown Prosecution Service. (2018). Jury Vetting. Retrieved 10.7.2018, from https://www.cps.gov .uk/legal-guidance/jury-vetting.

Dawson, J., Kersley, R., \& Natella, S. (2014). The CS Gender 3000: Women in Senior Management. Retrieved 23.11.2016, from https://publications.credit-suisse.com/tasks/render/file/inde x.cfm?fileid=8128F3C0-99BC-22E6-838E2A5B1E4366DF.

Denrell, J., Fang, C., \& Liu, C. (2019). In Search of Behavioral Opportunities from Misattribution of Luck. Academy of Management Review (forthcoming).

Denrell, J., \& Liu, C. (2012). Top performers are not the most impressive when extreme performance indicates unreliability. Proceedings of the National Academy of Sciences, 109(24), 93319336.

Dobelli, R. (2013). The Art of Thinking Clearly: Better Thinking, Better Decisions. London: Hodder $\&$ Stoughton Ltd.

Dryzek, J.S. (2000). Deliberative democracy and beyond: Liberals, critics, contestation. Oxford, UK: Oxford University Press.

Dwenger, N., Kübler, D., \& Weizsäcker, G. (2014). Flipping a Coin: Theory and Evidence. CESifo Working Papier No. 4740. 
Emery, F.E. (1989). Toward Real Democracy. Toronto: Ontario Quality of Working Life Centre.

Fischhoff, B. (1975). Hindsight is not equal to foresight: The effect of outcome knowledge on judgment under uncertainty. Journal of Experimental Psychology: Human Perception and Performance, 1(3), 288-299.

Fishkin, J.S. (1991). Democracy and deliberation: New directions for democratic reform. New Haven, CT: Yale University Press.

Frank, R.H. (2016). Success and Luck: Good Fortune and the Myth of Meritocracy. Princeton: Princeton University Press.

Frey, B.S. (1969). Wahrscheinlichkeiten als gesellschaftliche Entscheidungsregel. Wirtschaft und Recht, 21, 14-26.

Frey, B.S. (1983). Democratic Economic Policy: A Theoretical Introduction. Oxford: Martin Robertson.

Frey, B.S. (2020). Can Random Procedures Improve Government Behaviour? ZFO Führung \& Organisation, Special issue on "Leadership and Luck" (forthcoming).

Frey, B.S., \& Eichenberger, R. (1994). Economic incentives transform psychological anomalies. Journal of Economic Behavior and Organization, 23(2), 215-234.

Frey, B.S., \& Gallus, J. (2013). Aggregate Effects of Behavioral Anomalies: A New Research Area. ECONOMICS Discussion Paper No. 2013-51.

Frey, B.S., \& Osterloh, M. (2016). Aleatoric Democracy. CESifo Working Paper No. 6220.

Frey, B.S., Osterloh, M., \& Rost, K. (2020). CEO by Lot. ZFO Zeitschrift Führung \& Organisation, Special issue on "Leadership and Luck" (forthcoming).

Frey, B.S., \& Steiner, L. (2014). God does not play dice, but people should: random selection in politics, science and society. CREMA (Center for Research in Economics, Management and the Arts) Working Paper No. 2014-09.

Frey, B.S., \& Stutzer, A. (2006a). Does the political process mitigate or accentuate individual biases due to mispredicting future utility? In: E.J. McCaffery \& J. Slemrod (eds.), Behavioral public finance: Toward a new agenda (pp. 113-140). New York: Russell Sage Foundation.

Frey, B.S., \& Stutzer, A. (2006b). Strengthening the citizens' role in international organizations. Review of International Organizations, 1(1), 27-43.

German Volkswagen Foundation. (2018). Experiment! In search of bold research ideas. Retrieved 12.9.2019, from https://www.volkswagenstiftung.de/sites/default/files/downloads/MB_100_e. pdf.

Gigerenzer, G., \& Selten, R. (eds.) (2002). Bounded Rationality: The Adaptive Toolbox. Cambridge, MA: The MIT Press.

Gigerenzer, G., Todd, P.M., \& the ABC Research Group. (eds.) (1999). Simple Heuristics That Make Us Smart. Oxford, New York: Oxford University Press.

Gladwell, M. (2008). Outliers: The story of success. London: Allen Lane.

Grandori, A. (2013). Models of rationality in economic organization. In: A. Grandori (ed.), Handbook of Economic Organization: Integrating Economic and Organization Theory (pp. 9-24). Northampton, MA: Edward Elgar Publishing.

Gupta, V.K., Mortal, S., Chakrabarty, B., Guo, X., \& Turban, D.B. (2019). CFO Gender and Financial Statement Irregularities. Academy of Management Journal (forthcoming).

Habermas, J. (2006). Political communication in media society. Communication Theory, 16, 411426. 
Health Research Council of New Zealand. (2019). 2020 Explorer Grant Application Guidelines. Retrieved 12.9.2019, from https://gateway.hrc.govt.nz/funding/researcher-initiated-proposals/ 2020-explorer-grants.

Heinzmann, S. (2020). The big lot - applications today. ZFO Zeitschrift Führung \& Organisation, Special issue on "Leadership and Luck" (forthcoming).

Intriligator, M.D. (1973). A Probabilistic Model of Social Choice. Review of Economic Studies, 40, 553-560.

Kahneman, D. (2011). Thinking, Fast and Slow. New York: Farrar, Straus and Giroux.

Knight, F. (1921). Risk, Uncertainty, and Profit. Boston, New York: Houghton Mifflin Company.

Liu, C. (2020). Luck: The Brilliant Randomness in Management. ZFO Zeitschrift Führung \& Organisation, Special issue on "Leadership and Luck" (forthcoming).

Liu, C., \& De Rond, M. (2016). Good Night and good Luck Perspectives on Luck in Management Scholarship. The Academy of Management Annals, 10(1), 409-451.

Luft, J., \& Ingham, H. (1955). The Johari window, a graphic model of interpersonal awareness. Proceedings of the Western Training Laboratory in Group Development. Los Angeles, CA: University of California.

Manin, B. (1997). The principles of representative government. Cambridge: Cambridge University Press.

Mansbridge, J. (2005). The fallacy of tightening the reins. Österreichische Zeitschrift für Politikwissenschaft, 34(3), 233-248.

Merton, R.K., \& Barber, E. (2004). The Travels and Adventures of Serendipity: A Study in Sociological Semantics and the Sociology of Science. Princeton: Princeton University Press.

Minkler, A.P. (1993). The Problem with dispersed Knowledge: firms in Theory an Practice. Kyklos, 46, 569-587.

Niederle, M., Segal, C., \& Vesterlund, L. (2013). How costly is diversity? Affirmative action in light of gender differences in competitiveness. Management Science, 59(1), 1-16.

Niederle, M., \& Vesterlund, L. (2007). Do women shy away from competition? Do men compete too much? The Quarterly Journal of Economics, 122(3), 1067-1101.

Niederle, M., \& Vesterlund, L. (2010). Explaining the gender gap in math test scores: The role of competition. Journal of Economic Perspectives, 24(2), 129-144.

OECD. (2015). The ABC of Gender Equality in Education: Aptitude, Behavior, Confidence. Retrieved 20.2.2017, from https://www.oecd.org/pisa/keyfindings/pisa-2012-results-gender-eng. pdf.

Osterloh, M., \& Frey, B.S. (2019). How to avoid borrowed plumes in academia. Research Policy, $49(1)$.

Osterloh, M., Goodall, A., \& Fong, M. (2019). Put the Women in Charge - by Lot. Working Paper University of Zurich.

Oswald, A. (2019). Rational Randomization by Journal Editors: A Mathematical Derivation. Research Policy (forthcoming).

Peel, R. (2018). Personality matters - 7 tips for building a PR profiling strategy. Retrieved Sept 10, 2019 from https:/www.agilitypr.com/pr-news/public-relations/personality-matters-7-tips-f or-building-a-pr-profiling-strategy/

Pitkin, H.F. (1967). The Concept of Representation. Berkeley: University of California Press. 
Pluchino, A., Biondo A.E., \& Rapisarda, A. (2018). Talent vs Luck: the role of randomness in success and failure. Advances in Complex systems, 21(3-4), 1-28.

Radner, R. (2000). Costly and bounded rationality in individual and team decision making, Industrial and Corporate Change, 9(4), 623-658.

Rost, K., \& Osterloh, M. (2010). Opening the black box of upper echelons: expertise and gender as drivers of poor information processing. Corporate Governance: An International Review, 18(3), 212-233.

Russo, J.E., \& Schoemaker, P.J.H. (1989). Decision Traps: The Ten Barriers to Decision-Making and How to Overcome Them. New York: Doubleday.

Sapienza, A., \& Weibel, A. (2017). The Good, the Not so Bad, and the Ugly of Competitive Human Resource Practices: A Multidisciplinary Conceptual Framework. Group \& Organization Management, 42(5), 707-747.

Schreyögg, G., \& Steinmann, H. (1987). Strategic Control: A New Perspective. The Academy of Management Review, 12(1), 91-103.

Shoucri, M. (1991). Patriarchal Election. In: A.S. Atiya (ed.), The Coptic Encyclopedia (pp. 19111912). New York: Macmillan Publishing Company.

Simon, H.A. (1955). A behavioral model of rational choice. The Quarterly Journal of Economics, 69, 99-118.

Simons, R. (1995). Levers of Control. How Managers Use Innovative Control Systems to Drive Strategic Renewal. Boston, MA: Harvard Business School Press.

Simonson, I. (1990). The Effect of Purchase Quantity and Timing on Variety-Seeking Behavior. Journal of Marketing Research, 27, 150-162.

Simonton, D.K. (2004). Creativity in Science. Chance, Logic, Genius, and Zeitgeist. Cambridge, UK: Cambridge University Press.

Sintomer, Y. (2011). Petite histoire de l'expérimentation démocratique. Tirage au sort et politique d'Athènes à nos jours. Paris: Éditions La Découverte.

Sintomer, Y. (2018). From Deliberation to Radical Democracy? Sortition and Politics in the Twenty-First Century, Politics and Society, 46(3), 337-357.

Stephan, P.E. (1996). The economics of science. Journal of Economic Literature, 34, 1199-1235.

Stolz, P. (1986). Parteienwettbewerb, politisches Kartell und Tausch zwischen sozioökonomischen Gruppen. Schweizerische Zeitschrift für Volkswirtschaft und Statistik, 122, 657-675.

Sugden, R. (2017). Do people really want to be nudged towards healthy lifestyles? International Review of Economics, 64(2), 113-123.

Taleb, N.N. (2001). Fooled by Randomness: The Hidden Role of Chance in Life and in the Markets. New York: Random House.

Taleb, N.N. (2007). The Black Swan: The Impact of the Highly Improbable. New York: Random House.

Taleb, N.N. (2012). Antifragile: Things That Gain from Disorder. New York: Random House.

Thaler, R.H., \& Sunstein, C.R. (2009). Nudge: Improving decisions about health, wealth, and happiness. London: Penguin Books Ltd.

Tversky, A., \& Kahneman, D. (1974). Judgment under uncertainty: Heuristics and biases. Science, $185,1124-1131$. 
Van Reybrouck, D. (2016). Against Elections. The Case for Democracy. London: Penguin Random House.

Zeitoun, H., Osterloh, M., \& Frey, B.S. (2014). Learning from Ancient Athens: Demarchy and corporate governance. Academy of Management Perspectives, 28(1), 1-14. 